\title{
Effect of plant growth promotion fungi on agricultural crops
}

\author{
Yelena Brazhnikova ${ }^{*}$, Lyudmila Ignatova ${ }^{1}$, Anel Omirbekova ${ }^{1}$, Togzhan Mukasheva ${ }^{\text {, }}$, \\ Aida Kistaubayeva ${ }^{~}$, Irina Savitskaya ${ }^{l}$, Dilfuza Egamberdieva ${ }^{2}$, Aizhamal Usmanova ${ }^{\text {, }}$, \\ and Irina Batlutskaya ${ }^{3}$ \\ ${ }^{1}$ Al-Farabi Kazakh National University, Department of biotechnology, 050040, Almaty, Kazakhstan \\ ${ }^{2}$ Leibniz Centre for Agricultural Landscape Research (ZALF), Müncheberg, Germany \\ ${ }^{3}$ Belgorod State National Research University, 308015, Belgorod, Russia
}

\begin{abstract}
Pot experiments with seven agricultural crops were carried out in laboratory conditions to study the effect of fungal strains on their growth and development: soybean (Glycine max), barley (Hordeum vulgare), alfalfa (Medicago sativa), rapeseed (Brassica napus), safflower (Carthamus tinctorius), sweet clover (Melilotus officinalis), sainfoin (Onobrychis viciifolia). Five fungal strains with biotechnologically valuable properties were used: $P$. bilaiae $\mathrm{Pb} 14, P$. bilaiae $\mathrm{C} 11, T$. pinophilus $\mathrm{T} 14$, Aspergillus sp. D1 and B. bassiana T7. Inoculation with fungal strains increased theshoot length of seedlings by $14-33 \%$, the root length by $13-29 \%$, the shoot dry weight by $12-31 \%$, the root dry weight by $15-30 \%$ compared to the controls. The application of fungal strains had a stimulating effect on the photosynthetic activity of plants by increasing the content of chlorophyll in the leaves of seedlings. There was an increase in the content of chlorophyll $a$ by $8-16 \%$, chlorophyll $b$ - by $9-17 \%$.
\end{abstract}

Keywords: fungi, plant growth promotion, agricultural crops.

\section{Introduction}

One of the current trends in the development of sustainable agriculture is the microbial biotechnology. Plant growth-promoting fungi (PGPF) are a diverse group of nonpathogenic fungi that provide a complex of beneficial effects to their host plants. PGPF can be separated into endophytic, which live inside plant tissues and exchange metabolites with plants directly; epiphytic, which live freely on the plant surface; and free-living PGPF, which live outside plant cells, i.e., in the rhizosphere [1,2].

Genera Aspergillus, Fusarium, Penicillium, Phoma and Trichoderma have a wide distribution among the PGPF and they are the most frequently reported [3-7].

The interest in PGPF is associated with their possibility to increase the yield of agricultural crops by restoring soil fertility, improving germination, seedling vigor, plant growth, root morphogenesis, photosynthesis, and flowering through direct and/or indirect mechanisms. The main mechanisms of PGPF include solubilization and mineralization of

\footnotetext{
*Corresponding author: PoLB_4@ mail.ru
} 
nutrients for their easy uptake by plants, productionof hormones, volatile organic compounds, and enzymes, suppression of plant pathogens and mitigation of abiotic stresses $[1,8]$.

Thus, the application of PGPF is one of the eco-friendly strategies of increasing crop production. The aim of this research was to study the influence of five fungal strains on the growth and development of seven agricultural crops.

\section{Materials and Methods}

\subsection{Fungal strains}

Five fungal strains were obtained from the Collection of Effective Agricultural Fungal Strains (CEAFS, Department of Biology and Biotechnology, al-Farabi Kazakh National University, Almaty, Kazakhstan). The characteristics of the strains are presented in Table 1.

Table 1. Characteristics of plant growth-promotingproperties of fungal strains

\begin{tabular}{|c|c|c|c|c|c|c|}
\hline & & $\begin{array}{l}\text { P. bilaiae } \\
\text { Pb14 }\end{array}$ & $\begin{array}{l}\text { P. bilaiae } \\
\text { C11 }\end{array}$ & $\begin{array}{l}\text { T. pinophilus } \\
\text { T14 }\end{array}$ & $\begin{array}{l}\text { Aspergillus } \\
\text { sp. D1 }\end{array}$ & $\begin{array}{c}B . \\
\text { bassian } \\
\text { a } \mathrm{T} 7\end{array}$ \\
\hline \multirow{3}{*}{$\begin{array}{l}\text { Production of } \\
\text { hydrolytic } \\
\text { enzymes }\end{array}$} & amylase & + & + & + & + & + \\
\hline & protease & + & - & + & + & + \\
\hline & lipase & + & + & - & + & + \\
\hline \multirow{2}{*}{$\begin{array}{l}\text { Mobilization } \\
\text { of } \mathrm{P} \\
\text { compounds }\end{array}$} & organic $\mathrm{P}$ & + & + & + & + & - \\
\hline & $\begin{array}{c}\text { inorganic } \\
\mathrm{P}\end{array}$ & + & + & + & + & - \\
\hline $\begin{array}{c}\text { Cellulolytic } \\
\text { activity }\end{array}$ & & + & + & + & + & - \\
\hline \multirow[t]{2}{*}{$\begin{array}{l}\text { Antagonistic } \\
\text { activity }\end{array}$} & $\begin{array}{c}\text { Fusarium } \\
\text { solani }\end{array}$ & - & + & - & + & + \\
\hline & $\begin{array}{c}\text { Alternaria } \\
\text { alternata }\end{array}$ & - & + & - & + & + \\
\hline \multirow{3}{*}{$\begin{array}{l}\text { Resistance to } \\
\text { heavy metals }\end{array}$} & $\mathrm{Pb}^{2+}$ & - & - & - & + & + \\
\hline & $\mathrm{Cd}^{2+}$ & - & - & + & - & + \\
\hline & $\mathrm{Zn}^{2+}$ & + & - & - & - & + \\
\hline
\end{tabular}

“+” indicates positive and ".-" indicates negative

\subsection{Fungal inoculum preparation}

The spore suspension was prepared according to the method [9] with some modifications. Each fungal strain was cultivated on Sabouraud dextrose agar medium for 7 days at $25{ }^{\circ} \mathrm{C}$. Spores were collected by scraping the surface of a sporulating culture into $3 \mathrm{ml}$ sterile water. The suspension was then adjusted to $50 \mathrm{ml}$. The final concentration of spore suspension was adjusted to $10^{7}$ spore $\mathrm{mL}^{-1}$. Using haemocytometer. Each Erlenmeyer flask $(150 \mathrm{~mL})$ containing $60 \mathrm{~mL}$ of sterilized liquid Sabouraud dextrose medium was inoculated with $1 \mathrm{ml}$ of the spore suspension. Cultures were incubated at $180 \mathrm{rpm}$ at $25{ }^{\circ} \mathrm{C}$ for 7 days. After incubation, the purified fungi were used to produce spore suspension for inoculation. A drop of Tween- 80 was added to each flask with culture medium and the spores of fungal strain were shocked off in sterile water. The spore suspension was filtered through a Whattman Paper No. 3, followed by filtration through $0.22 \mathrm{~mm}$ Millipore membranes. It was then adjusted to $10^{7}$ spore $\mathrm{mL}^{-1}$.

To prepare inoculum, the spore suspensions of each fungal strain were mixed in equal proportions. 


\subsection{Pot experiment}

Seeds of seven agricultural crops were used in the experiments: soybean (Glycine max), barley (Hordeum vulgare), alfalfa (Medicago sativa), rapeseed (Brassica napus), safflower (Carthamus tinctorius), sweet clover (Melilotus officinalis), sainfoin (Onobrychis viciifolia). Seeds were previously surface sterilized by soaking in $75 \%$ ethanol for $5 \mathrm{~min}$, in $1 \%$ sodium hypochlorite for $10 \mathrm{~min}$, followed by thoroughly rinsing in sterile distilled water. Pots were filled with dry nonsterilized dark chestnut soil. Soil moisture was maintained at $60 \%$ of the whole water-holding capacity by addition of distilled water. Sterilized seeds were placed in pots ( 15 seeds per pot, 5 pots per treatment) and each seed was immediately inoculated with $1 \mathrm{~mL}$ of fungal spore suspension containing $10^{7}$ spore $\mathrm{mL}^{-1}$. Seeds treated with sterile water were used as control. After incubation for 30 days the plants were harvested and the length and dry weight of shoots and roots were determined.

\subsection{Chlorophyll content estimation}

Chlorophyll content estimation was carried out by the method [10]. Fresh leaves $(0.5 \mathrm{~g})$ of each plant sample were homogenized. Five $\mathrm{mL}$ of $96 \%$ ethanol was added. Then the sample was filtered, and the final volume $(50 \mathrm{~mL})$ was achieved using $96 \%$ ethanol. Finally, absorbance was measured spectrophotometrically at 649 and $665 \mathrm{~nm}$ against $96 \%$ ethanol as blank. The chlorophyll content was calculated using following Equations and expressed in mg per g of fresh weight:

$$
\begin{aligned}
& \text { Chlorophyll } \mathrm{a}=\frac{(13.7 \text { OD } 665-5.76 \text { OD } 649) \times \mathrm{V}}{1000 \times W} \\
& \text { Chlorophyll } \mathrm{b}=\frac{(25.80 \mathrm{D} 649-7.600 \mathrm{OD} 665) \times \mathrm{V}}{1000 \times W} \\
& \text { Total chlorophyll }=\frac{(6.10 \mathrm{OD} 665+20.4 \mathrm{OD} 649) \times \mathrm{V}}{1000 \times W}
\end{aligned}
$$

where OD - optical density $(\mathrm{nm}), \mathrm{V}$ - final volume made $(\mathrm{mL}), \mathrm{W}$ - fresh weight of leaves (g)

\subsection{Statistical analysis}

The data were processed using the software Statistica version 10.0 (TIBCO Software Inc., CA, USA). Student's t-test $(p<0.05)$ was performed to estimate statistical differences between means. SD stands for standard deviation.

\section{Results and discussion}

In the present study it was revealed, that inoculation with fungi significantly $(\mathrm{p}<0.05)$ increased seed germination and morphological parameters of all agricultural crops including shoot and root length and plant dry weight (Table 2). However, the responses of the crops to the fungal inoculation varied.

In the most cases treatment with fungal strains improved seed germination (Fig.1). However, seed germination of alfalfa, safflower and sainfoin were not affected by fungal inoculation. Barley showed the highest seedgermination percentages and root length.

Root length is one of the most important characters because roots are in contact with soil and absorb water with mineral compounds from soil. For this reason, root length provides an important clue to the response of plants to growth promotion. Among the agricultural crops, the greatest root elongation (by 29\%) was observed in barley, followed by sweet clover which 
demonstrated root elongation by $27 \%$ (Table 2). There was one exception with safflower. Treatment with fungi significantly increased the shoot length of safflower (by $21 \%$ ), but did not affect the root length (Fig.2).

Table 2 Effects of inoculation with fungal strains on the growth parameters of crop seedlings

\begin{tabular}{|c|c|c|c|c|c|}
\hline \multirow{2}{*}{$\begin{array}{c}\text { Agricultural crop } \\
\text { Treatment }\end{array}$} & $\begin{array}{c}\text { Shoot } \\
\text { length, cm }\end{array}$ & $\begin{array}{c}\text { Root length, } \\
\text { cm }\end{array}$ & $\begin{array}{c}\text { Shoot dry } \\
\text { weight, } \\
\text { plant }\end{array}$ & $\begin{array}{c}\text { Root dry } \\
\text { weight, } \\
\text { plant }\end{array}$ \\
\hline $\begin{array}{c}\text { Soybean } \text { (Glycine } \\
\text { max) }\end{array}$ & Control & $31.1 \pm 1.4 \mathrm{a}$ & $19.8 \pm 0.5 \mathrm{a}$ & $0.94 \pm 0.04 \mathrm{a}$ & $0.19 \pm 0.005 \mathrm{a}$ \\
\hline & Fungal inoculation & $41.4 \pm 1.8 \mathrm{~b}$ & $22.3 \pm 0.9 \mathrm{~b}$ & $1.23 \pm 0.05 \mathrm{~b}$ & $0.23 \pm 0.01 \mathrm{~b}$ \\
\hline $\begin{array}{c}\text { Barley (Hordeum } \\
\text { vulgare) }\end{array}$ & Control & $37.2 \pm 1.5 \mathrm{a}$ & $13.8 \pm 0.4 \mathrm{a}$ & $0.31 \pm 0.01 \mathrm{a}$ & $0.09 \pm 0.005 \mathrm{a}$ \\
\cline { 2 - 6 } & Fungal inoculation & $44.4 \pm 1.7 \mathrm{~b}$ & $17.8 \pm 0.7 \mathrm{~b}$ & $0.38 \pm 0.01 \mathrm{~b}$ & $0.11 \pm 0.004 \mathrm{~b}$ \\
\hline $\begin{array}{c}\text { Alfalfa (Medicago } \\
\text { sativa) }\end{array}$ & Control & $29.2 \pm 1.2 \mathrm{a}$ & $15.2 \pm 0.5 \mathrm{a}$ & $0.2 \pm 0.01 \mathrm{a}$ & $0.09 \pm 0.004 \mathrm{a}$ \\
\cline { 2 - 6 } & Fungal inoculation & $33.3 \pm 1.4 \mathrm{~b}$ & $17.9 \pm 0.8 \mathrm{~b}$ & $0.23 \pm 0.01 \mathrm{~b}$ & $0.1 \pm 0.003 \mathrm{~b}$ \\
\hline $\begin{array}{c}\text { Rapeseed (Brassica } \\
\text { napus) }\end{array}$ & Control & $20.5 \pm 0.8 \mathrm{a}$ & $6.9 \pm 0.2 \mathrm{a}$ & $0.21 \pm 0.005 \mathrm{a}$ & $0.04 \pm 0.001 \mathrm{a}$ \\
\cline { 2 - 6 } & Fungal inoculation & $25.1 \pm 1.1 \mathrm{~b}$ & $8.8 \pm 0.3 \mathrm{~b}$ & $0.28 \pm 0.01 \mathrm{~b}$ & $0.05 \pm 0.001 \mathrm{~b}$ \\
\hline $\begin{array}{c}\text { Safflower (Carthamus } \\
\text { tinctorius) }\end{array}$ & Control & $14.4 \pm 0.6 \mathrm{a}$ & $4.6 \pm 0.2 \mathrm{a}$ & $0.08 \pm 0.001 \mathrm{a}$ & $0.009 \pm 0.0002 \mathrm{a}$ \\
\cline { 2 - 6 } & Fungal inoculation & $17.8 \pm 0.5 \mathrm{~b}$ & $5.1 \pm 0.2 \mathrm{a}$ & $0.1 \pm 0.002 \mathrm{~b}$ & $0.011 \pm 0.0004 \mathrm{a}$ \\
\hline $\begin{array}{c}\text { Sweet clover } \\
\text { (Melilotus officinalis) }\end{array}$ & Control & $30.1 \pm 0.9 \mathrm{a}$ & $13.2 \pm 0.4 \mathrm{a}$ & $0.77 \pm 0.02 \mathrm{a}$ & $0.08 \pm 0.002 \mathrm{a}$ \\
\hline Sungal inoculation & $34.8 \pm 1.4 \mathrm{~b}$ & $16.8 \pm 0.7 \mathrm{~b}$ & $0.98 \pm 0.03 \mathrm{~b}$ & $0.1 \pm 0.001 \mathrm{~b}$ \\
\hline $\begin{array}{c}\text { Sainfoin(Onobrychis } \\
\text { viciifolia) }\end{array}$ & Control & $14.3 \pm 0.6 \mathrm{a}$ & $10.3 \pm 0.3 \mathrm{a}$ & $0.17 \pm 0.002 \mathrm{a}$ & $0,08 \pm 0.001 \mathrm{a}$ \\
\cline { 2 - 6 } & Fungal inoculation & $18.7 \pm 0.7 \mathrm{~b}$ & $12.4 \pm 0.3 \mathrm{~b}$ & $0.19 \pm 0.004 \mathrm{~b}$ & $0.09 \pm 0.03 \mathrm{~b}$ \\
\hline
\end{tabular}

Data are presented as means \pm SD. Different letters in the same subcolumn for each agricultural crop indicate statistically significant differences among values according to Student's t-test at the $\mathrm{p}<0.05$

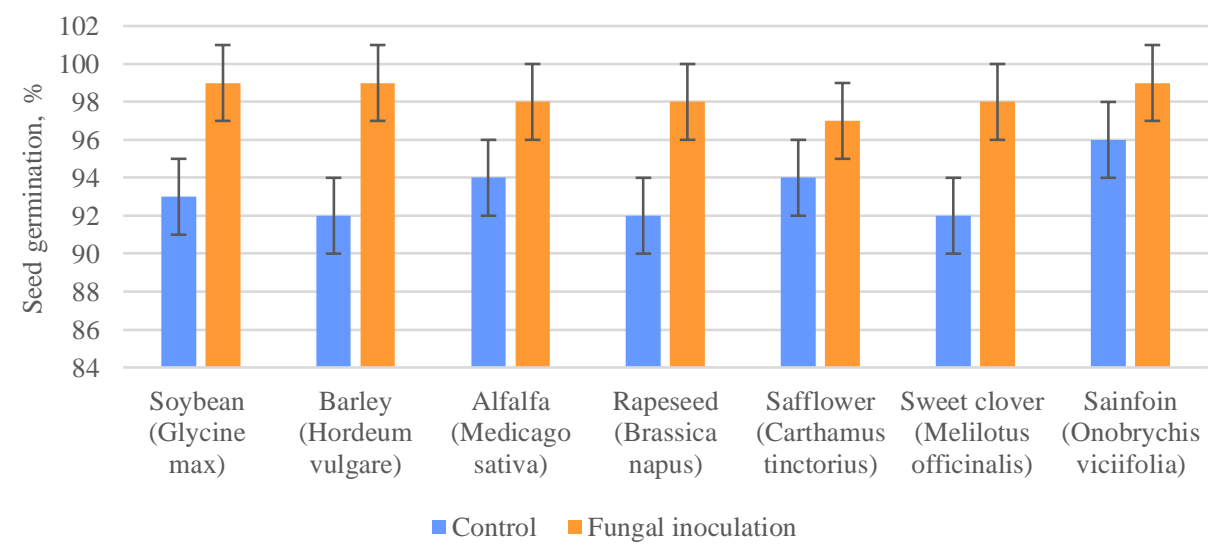

Fig. 1. Effect of inoculation with fungal strains on seed germination of agricultural crops

Inoculation with fungal strains enhanced shoot length by 14-33\%. The highest values of shoot length were determined invariants with soybean and sweet clover.Treatment with fungal strains also increased shoot weight by $12-31 \%$, and root weight by $15-30 \%$ compared to the control variants (Table 2).

The enhancement in seedling growth parameters after the application of fungal strains might be due to their ability to promote plant growth via direct and indirect mechanisms. Previous studies showed that application of plant growth-promoting fungi enhanced germination and seedling vigor, improved growth, nutrient content and yield of different crops, including alfalfa [6] and rapeseed [7]. As for soybean [11,12], barley [13,14] and safflower $[15,16]$, such effects were described for bacterial strains only. There are no data available in the previous reports about influence of plant growth-promoting microorganisms 
on sweet clover and sainfoin. Thus our study expands this information to five fungal species and seven agricultural crops.

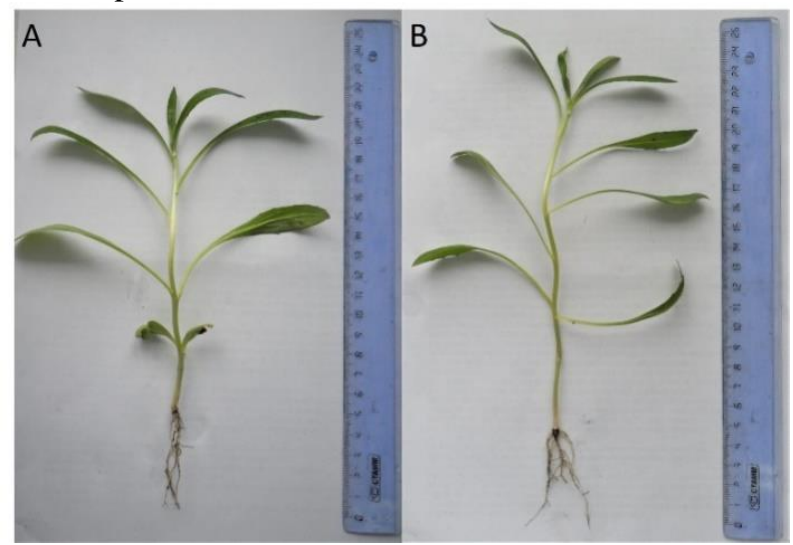

Fig. 2. Shoot and root length of 30 day-old seedlings of safflower (Carthamus tinctorius). A - control, $\mathrm{B}$ - inoculation with fungal strains

One of the important characteristics of the photosynthetic activity of plants is the content of pigments chlorophyll a and $b$. The stability of the photosynthetic system ensures the proportion of chlorophyll a to chlorophyll $b$, and the decrease in this indicator and a decrease in the total content of the chlorophyll indicate a violation of the photosynthetic activity of plants $[17,18]$. In the present study, treatment with fungal strains led to increase in content of a, b and total chlorophyll in 30 day-old seedlings of almost allagricultural crops. However, there were exceptions with the plants sweet clover and sainfoin. Although inoculation with fungi increased significantly theirgrowth parameters, it did not lead to the significant changes in chlorophyll content (Table 3).

Table 3. Effect of inoculation with fungal strains on chlorophyll content in agricultural crops

\begin{tabular}{|c|c|c|c|c|c|}
\hline $\begin{array}{l}\text { Agricultural } \\
\text { crop }\end{array}$ & Treatment & $\begin{array}{c}\text { Chlorophyll } a \\
\mathrm{mg} / \mathrm{g}\end{array}$ & $\begin{array}{c}\text { Chlorophyll } b \\
\mathrm{mg} / \mathrm{g}\end{array}$ & $\begin{array}{c}\text { Total } \\
\text { chlorophyll, } \\
\mathrm{mg} / \mathrm{g}\end{array}$ & $\begin{array}{c}\text { Chlorophyll } a \\
\text { / Chlorophyll } \\
b\end{array}$ \\
\hline \multirow{2}{*}{$\begin{array}{c}\text { Soybean } \\
\text { (Glycine } \max )\end{array}$} & Control & $1.21 \pm 0.05 \mathrm{a}$ & $0.52 \pm 0.01 \mathrm{a}$ & $1.73 \pm 0.06 \mathrm{a}$ & $2.32 \pm 0.1 \mathrm{a}$ \\
\hline & Fungal inoculation & $1,38 \pm 0.06 \mathrm{~b}$ & $0.58 \pm 0.02 b$ & $1.96 \pm 0.05 \mathrm{~b}$ & $0.1 \mathrm{a}$ \\
\hline \multirow{2}{*}{$\begin{array}{c}\text { Barley (Hordeum } \\
\text { vulgare) }\end{array}$} & Control & $0,77 \pm 0,02 \mathrm{a}$ & $0.31 \pm 0,01 \mathrm{a}$ & $1.08 \pm 0,01 \mathrm{a}$ & $2.48=$ \\
\hline & Fungal inoculation & $0.89 \pm 0.03 \mathrm{~b}$ & $.01 \mathrm{~b}$ & $1,25 \pm 0.05 \mathrm{~b}$ & $.1 \mathrm{a}$ \\
\hline \multirow{2}{*}{$\begin{array}{c}\text { Alfalfa } \\
\text { (Medicago } \\
\text { sativa) }\end{array}$} & Control & $0.75 \pm 0.02 \mathrm{a}$ & $0.43 \pm 0,01 \mathrm{a}$ & $1.18 \pm 0.04 \mathrm{a}$ & $1.74 \pm 0.05 \mathrm{a}$ \\
\hline & Fungal inoculation & $0.87 \pm 0.03 b$ & $0.47 \pm 0,01 \mathrm{~b}$ & $1.34 \pm 0.05 \mathrm{~b}$ & $1.85 \pm 0.03 \mathrm{~b}$ \\
\hline \multirow{2}{*}{$\begin{array}{c}\text { Rapeseed } \\
\text { (Brassica napus) }\end{array}$} & & $0,82 \pm 0,03 \mathrm{a}$ & $0,01 \mathrm{a}$ & $1,23 \pm 0,04 \mathrm{a}$ & $2 \pm 0.09 \mathrm{a}$ \\
\hline & Fungal inoculation & $0.88 \pm 0.02 \mathrm{~b}$ & 0.44 & $1.32 \pm 0.05 \mathrm{~b}$ & $5 \mathrm{a}$ \\
\hline \multirow{2}{*}{$\begin{array}{c}\text { Safflower } \\
\text { (Carthamus } \\
\text { tinctorius) }\end{array}$} & Control & $1.43 \pm 0.06 \mathrm{a}$ & $0.65 \pm 0.01 \mathrm{a}$ & $2.08 \pm 0.05 \mathrm{a}$ & $2.2 \pm 0.01 \mathrm{a}$ \\
\hline & Fungal inoculation & $1.61 \pm 0.07 \mathrm{~b}$ & $0.71 \pm 0.02 b$ & $2.32 \pm 0.03 \mathrm{~b}$ & $2.27 \pm 0.02 \mathrm{~b}$ \\
\hline \multirow{2}{*}{$\begin{array}{l}\text { Sweetclover } \\
\text { (Melilotus } \\
\text { officinalis) }\end{array}$} & Control & $1.33 \pm 0.03 \mathrm{a}$ & $0.51 \pm 0.02 \mathrm{a}$ & $1.84 \pm 0.05 \mathrm{a}$ & $2.61 \pm 0.1 \mathrm{a}$ \\
\hline & Fungal inoculation & $1.38 \pm 0.04 \mathrm{a}$ & $0.53 \pm 0.01 \mathrm{a}$ & $1.91 \pm 0.06 \mathrm{a}$ & $2.6 \pm 0.05 \mathrm{a}$ \\
\hline \multirow{2}{*}{$\begin{array}{c}\text { Sainfoin } \\
\text { (Onobrychis } \\
\text { viciifolia) }\end{array}$} & Control & $0.99 \pm 0.04 \mathrm{a}$ & $0.47 \pm 0.02 \mathrm{a}$ & $1.46 \pm 0.02 \mathrm{a}$ & $2.11 \pm 0.06 \mathrm{a}$ \\
\hline & Fungal inoculation & $1.03 \pm 0.03 \mathrm{a}$ & $0.44 \pm 0.02 \mathrm{a}$ & $1.47 \pm 0.04 \mathrm{a}$ & $2.34 \pm 0.1 \mathrm{a}$ \\
\hline
\end{tabular}

Data are presented as means \pm SD. Different letters in the same subcolumn for each agricultural crop indicate statistically significant differences among values according to Student's t-test at the $\mathrm{p}<0.05$ 
Application of fungal strains resulted in improvement of the chlorophyll a content by 8 $16 \%$, chlorophyll b - by $9-17 \%$. This might be due to production of some compounds by fungi that regulate transcription and translation of genes involved in chlorophyll biosynthesis and/or reduce the degradation of chlorophyll in plants. But further studies are needed to understand the observations.

\section{Conclusion}

The results of the conducted studies allow us to conclude that five fungal strains are promising and that they can be used to promote the growth and development of agricultural crops.

\section{References}

1. M.M. Hossain, F. Sultana, S. Islam Plant growth-promoting fungi (PGPF): Phytostimulation and induced systemic resistance. In Plant-Microbe Interactions in Agro-Ecological Perspectives, 2, 135 (2017)

2. M. Jia, L. Chen, H.L. Xin , C.J. Zheng, K. Rahman, T. Han, L.P. Qin, Front Microbiol. 7, 906 (2006)

3. J. Yadav, J.P. Verma, K.N Tiwari, Asian Journal of Biological Sciences. 4, 291 (2011)

4. R. Radhakrishnan, A.L. Khan, S.M. Kang, A.L. Lee, Annales de Microbiologie. 65(1), 585 (2015)

5. A.G. Babu, S.W. Kim, D.J. Yadav, U. Hyum, M. Adhikari, Y.S. Lee, Mycobiology. 43,49 (2015)

6. J. Liu, X. Liu, Q. Zhang, AMB Expr, 10 (2020)

7. Z.Z. Su, T. Wang, N. Shrivastava, Y.Y. Chen, X. Liu, C. Sun, Y. Yin, Q.K. Gao, B.G. Lou Jun, L. Microbiol (2017)

8. F. Pérez-Montaño, Microbiol Res. 169, 325 (2014)

9. S.W. Zhang, Y,T. Gan, Y.Y. Xue, B.L. Xu, Biol. Control, 72, 1 (2014)

10. J.F.G.M. Wintermans, A. De Mots, Biochimica et Biophysica Acta (BBA) - Biophysics including Photosynthesis 109,448 (1965)

11. J. Garcia, J.E. Schmidt, M. Gidekel, A. C. M. Gaudin Journal of Plant Nutrition, 44 (2021)

12. D.M. Zeffa, L.H. Fantin, A. Koltun, , A. de Oliveira, M. Nunes, M.L. Canteri, L. Gonçalves, PeerJ, 8, 7905 (2020)

13. A. Peix, A.A. Rivas-Boyero, D.F. Mateos, C. Rodriguez-Barrueco, E. Martínez-Molina, E. Velazquez, Soil Biol Biochem. 33,103 (2001)

14. M.Y. Canbolat, S.Bilen, R. Çakmakçı, F. Şahin, A. Aydın, Biol Fertil Soils. 42,350 (2006)

15. A. Nosheen, A. Bano, F. Ullah, U. Farooh, H. Yasmin, Ishtiaq, Hussain, Afr. J. Biotechnology. 10 (2011)

16. R. Sharifi, A. Namvar, Pesquisa Agropecuaria Brasileira 52, 236 (2017)

17. L.L. Eggink, H. Park, J.K. Hoober, BMC plant biology 2 (2001)

18. T. D. Sharkey, Emerg Top Life Sci. 4 (2), 137 (2020) 